\title{
Determination of Acidic Pharmaceuticals in Municipal Wastewater by Using Solid-Phase Extraction Followed by Gas Chromatography-Mass Spectrometry**
}

\section{Introduction}

Pharmaceuticals and their transformation products have been more frequently detected in aquatic environments over recent years. The presence of pharmaceuticals in environment systems for the first time was observed in 1970s in United States, when clofibric acid, salicylic acid and caffeine were detected in sewage effluent and in ground water (clofibric acid) [9]. Yet, it was only in the second half of the 1990s that scientific interest has grown significantly as a consequence of huge developments in analytical techniques. Moreover, the presence of pharmaceuticals in the environment has raised awareness of the risk that pharmaceuticals may pose on aquatic organisms due to their biological activity and possible long-term exposure [23].

Drugs, after oral administration are excreted from the body either as metabolites or as the parent compounds and through the domestic sewage system they reach municipal wastewater treatment plant. Recent studies showed, that conventional wastewater treatment procedures consisting of physical, chemical and biological processes are insufficient to eliminate these micro contaminants completely, thus effluents have been recognized as a major source of pharmaceuticals entering the aquatic environment $[3,10,11,26]$. Residues of pharmaceuticals are being detected mainly in Western Europe and USA water environment at the level of ppt to ppb in sewage effluents $[25,26]$, in surface water $[2,30]$ and even in drinking water sources $[1,8]$. So far, there has been just few publications on their occurrence in Polish water bodies. In 2005, the presence of 23 pharmaceuticals from different therapeutic classes in raw wastewater from Zabrze up to $27 \mu \mathrm{g} / \mathrm{L}$ was revealed [7]. In the same year, scientists from Gdansk University of Technology determined the presence of non-steroidal anti-inflammatory drugs (NSAIDs) in surface water up to $\sim 0.5 \mu \mathrm{g} / \mathrm{L}$ [5]. Kasprzyk-Hordern et al. [13,14] published results of determination of numerous

* AGH University of Science and Technology, Faculty of Energy and Fuels, Department of Coal Chemistry and Environmental Sciences, Krakow, Poland

** This work was supported by National Science Centre grant no 18.18.210.223 
group of pharmaceuticals in the Warta river, influent and effluent from wastewater treatment plants. The most studied pharmaceuticals were found at a concentration of up to $2.1 \mu \mathrm{g} / \mathrm{L}, 10 \mu \mathrm{g} / \mathrm{L}$ and $2.8 \mu \mathrm{g} / \mathrm{L}$, respectively.

In general, residues of pharmaceuticals are continuously delivered to environment in trace levels but the problem may grow due to the increasing consumption and world production of pharmaceuticals. Global pharmaceutical market was estimated to reach $\$ 808$ billion in 2009 with 5-7\% growth rate in the last years. According to the latest reports (PMR Publications) Polish pharmaceutical market is the sixth one in the Europe with the sales of nearly PLN 30 billion in 2010 [17]. Around 34\% of pharmacy sales are generated by OTC (over the counter) products whereas $26 \%$ of OTC market comes from analgesic drugs [16]. Because of general accessibility and overusing, OTC drugs are most often detected in aquatic systems in arelatively high concentration level [6].

So far, there is no systematic monitoring of pharmaceutical residues in waters and no standardized analytical methods available. For these reasons the aim of this work was to present sensitive analytical method for detection of selected nonsteroidal anti-inflammatory drugs in wastewater by solid phase extraction followed by gas chromatography mass-spectrometry.

\section{Experimental}

\subsection{Materials and Chemicals}

In this study five selected pharmaceuticals or chemicals associated with pharmaceuticals were selected for analysis. The selection included several nonsteroidal anti-inflammatory drugs - naproxen, ketoprofen and diclofenac. Bisphenol A, a chemical used to manufacture polycarbonate plastics, suspected to be also an endocrine disruptor with potential to mimic the role of the natural hormones, was also included. Moreover, triclosan, an antibacterial and antifungal agent, which with chlorine can form carcinogenic chloroform, was also taken into consideration. The structures of the pharmaceuticals considered in this study are shown in figure 1.

Standards were of the following origins: naproxen and ketoprofen from Sigma-Aldrich (St. Louis, MO, USA), diclofenac sodium and bisphenol A from Dr. Ehrenstorfer (Augsburg, Germany) and triclosan from Merck (Darmstadt, Germany). 1-hydroxypiren used as internal standard was obtained from Sigma-Aldrich (St. Louis, MO, USA). Stock solutions of all compounds were prepared in ethyl acetate. Silylating agent, N-Methyl-N-(trimethylsilyl)trifluoroacetamide (MSTFA) was from Sigma-Aldrich (St. Louis, MO, USA).

All solvents were of analytical grade of high residue purity. Methanol, n-hexane and hydrochloric acid were purchased from POCH (Gliwice, Poland). Ethyl acetate was purchased from Merck (Darmstadt, Germany). Ultrapure water was obtained from an HLP5 system (Hydrolab, Poland). 


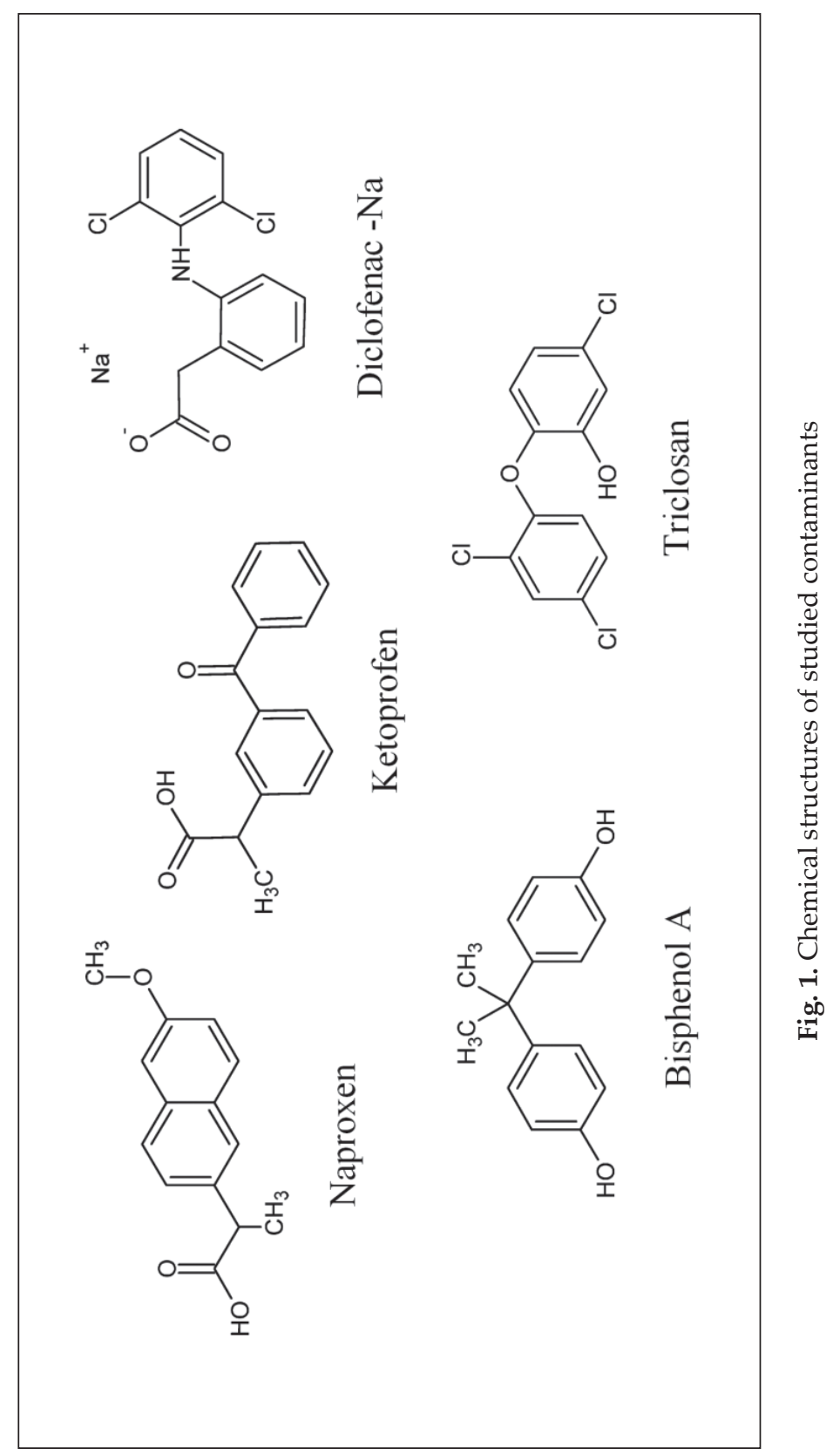


Glass-fiber filter papers GF-4 and GF-1 $(\varnothing=45 \mathrm{~mm})$ used in samples pre-treatment were purchased from Macherey-Nagel (Düren, Germany). The cartridges used for solid phase extraction were Oasis HLB 60mg from Waters (Ireland).

\subsection{Sample Collection and Pre-Preparation}

Wastewater samples were collected in January 2011 from Plaszow Wastewater Treatment Plant in Krakow. This is a conventional sewage plant consisting of pre-treatment followed by a secondary activated sludge treatment. The design capacity of the plant is 656 thousand $\mathrm{m}^{3}$ per day but it threats approximately 165 thousand $\mathrm{m}^{3}$ of urban wastewater per day, what is over $70 \%$ of the total volume of the city's wastewater. Effluents are discharged to the Drwina river and then to the Vistula river.

Both, influent and effluent samples were taken early in the morning and collected in 5L plastic containers. Samples were stored at $4^{\circ} \mathrm{C}$ until further processing. Next, the samples were filtered with glass fiber filters and extraction was performed during the day of the sampling.

\subsection{Solid-Phase Extraction}

Because of low concentration of pharmaceuticals in environmental water samples pre-concentration steps are necessary before analysis.

Pre-concentration and clean-up steps were accomplished by solid-phase extraction using Oasis HLB extraction cartridges. The SPE procedure was based mostly on our own previous investigations and optimization experience reported in the literature [19, 21]. Oasis HLB is a universal polymeric sorbent for acidic, neutral and basic compounds. In order to enhance recoveries, analytes (all weak acids) were conducted to non-ionic form through adjusting $\mathrm{pH}$ of wastewater samples to 2.0 with $2 \mathrm{M}$ hydrochloric acid. Extraction was carried out on a SPE-12G (JT Baker) vacuum manifold system.

Before sample loading, SPE cartridges were conditioned with $3 \mathrm{~mL}$ of ethyl acetate, $3 \mathrm{~mL}$ methanol and $3 \mathrm{~mL}$ deionized water at adjusted $\mathrm{pH}$ 2.0. $250 \mathrm{~mL}$ of influent, and $500 \mathrm{~mL}$ of effluent were then transferred to the SPE cartridges at flow rate up to $10 \mathrm{~mL} / \mathrm{min}$. After the extraction, cartridges were washed with $3 \mathrm{~mL}$ of methanol:water (5:95, v/v) and $1 \mathrm{~mL}$ of $\mathrm{n}$-hexane and then dried for 15 minutes under a vacuum. The elution was performed with $3 \mathrm{~mL}$ of ethyl acetate at flow rate of about $1 \mathrm{~mL} / \mathrm{min}$. The extracts were evaporated to dryness with a Six Port Mini-Vap Evaporator from Supelco (Bellefonte, PA, USA) at $45^{\circ} \mathrm{C}$ in a water bath under a gentle flow of argon. Finally, dry residues were dissolved in $0.1 \mathrm{~mL}$ of $5 \mu \mathrm{g} / \mathrm{mL}$ of 1 -hydroxypyrene in ethyl acetate. 1-hydroxypyrene was used to compensate possible loss of the sample during injection.

For recovery studies, ultrapure water was spiked with each of target compounds before the SPE process and before the derivatization step at a concentration of $0.5 \mu \mathrm{g} / \mathrm{L}$ and $1.0 \mu \mathrm{g} / \mathrm{L}$. 


\subsection{Derivatization for GC/MS Detection}

To increase the volatility and stability silylation of analytes with the $\mathrm{N}$-methy-N-(trimethylsilyl) trifluoroacetoamide (MSTFA) was performed. Silylation is the prevalent type of derivatization used in GC/MS analysis of hydroxyl compounds. Therefore, $50 \mu \mathrm{L}$ of concentrated wastewater was mixed with $15 \mu \mathrm{L}$ of MSTFA [24]. Samples were heated at $65^{\circ}$ for 35 minutes using digital dry bath thermo-block Labnet (NJ, USA) and subsequently analyzed in a GC/MS system.

\subsection{Calibration Method}

Standard addition calibration was used for quantification due to existing matrix effects. 1-hydroxypyrene was used as an internal standard to control sample volume during manual injection.

Repeatability of parallel injection expressed as a variation coefficient $(n=3)$ ranged from $0.2 \%$ for naproxen to $9 \%$ for diclofenac, which seems to be satisfactory for wastewater matrix. Limits of detection (LOD) and limits of quantification (LOQ) for the presented method were determined experimentally, both in influent and effluent samples, according to standard procedures, by measuring the signal to noise ratio $(\mathrm{S} / \mathrm{N})$. LOD was estimated as three times noise value measured around the analyte retention time $( \pm 0.5 \mathrm{~min})$ and LOQ was estimated as three times of the LOD value. For calibration, five standard mixtures containing internal standard and test compounds in concentration within $0.5-15.0 \mu \mathrm{g} / \mathrm{mL}$ were analyzed. The expected model for the data is linear regression $y=b x+a$, where $a$ is the theoretical $y$-intercept and $b$ is the theoretical slope $(x-$ analyte concentration in the sample, $\mu \mathrm{g} / \mathrm{mL}$, $y$ - peak area ratio: analyte to internal standard). Before accepting linear model, the fitting of a linear regression was considered using $R$ (software for statistical computing and graphics), by comparing linear $(y \sim x)$ and quadratic model $\left(y \sim x+I\left(x^{2}\right)\right)-$ Mandel test [4]. The null hypothesis in this case is $H_{0}: I\left(x^{2}\right)=0$, that quadratic model does not fit. Additional criteria is AIC (Akaike's Information Criterion) - a measure of the relative goodness of fit of a statistical model (AIC $=2 k-2 \ln (L)$, where $k$ is the number of parameters in the statistical model and $L$ is the value of the likelihood for the estimated model). The model to choose is the one for which AIC is least (Tab. 1).

After choosing a linear model as a better option for the evaluated data, linear regression analysis (least squares method) was held to predict the unknown concentrations of tested compounds in wastewater samples (Tab. 1). In order to ensure the accuracy of estimates, the significance of model regression was checked by the Student's $t$-test [15]. Hypothesis tests were conducted to show statistically significant difference between slope $b$ and zero, and no significant difference between theoretical $y$-intercept a and experimental $\left|a_{0}\right|(y$ value at $x=0)$. In the end, the strong linear relationships among variables $x$ and $y$ was statistically confirmed. 


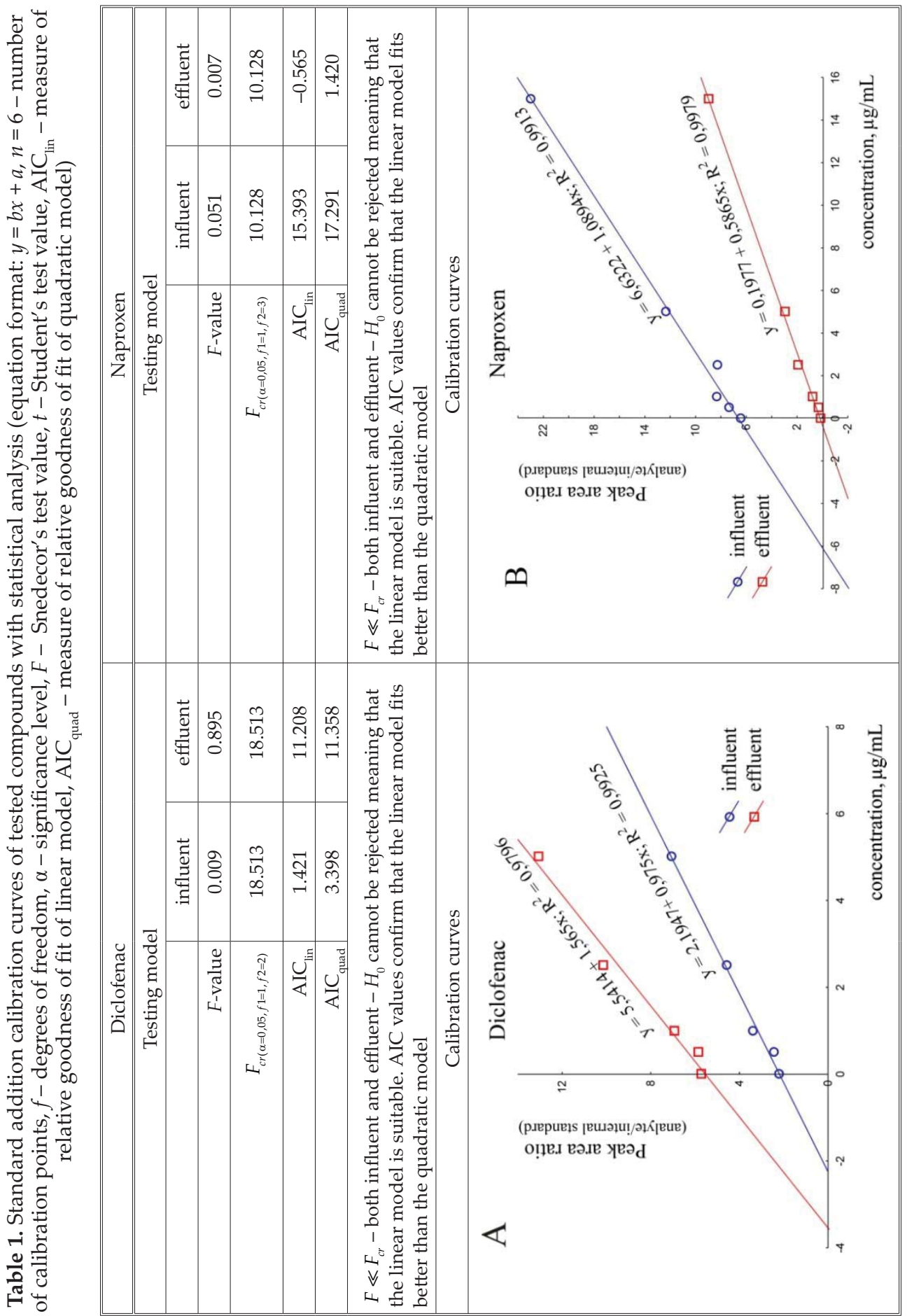




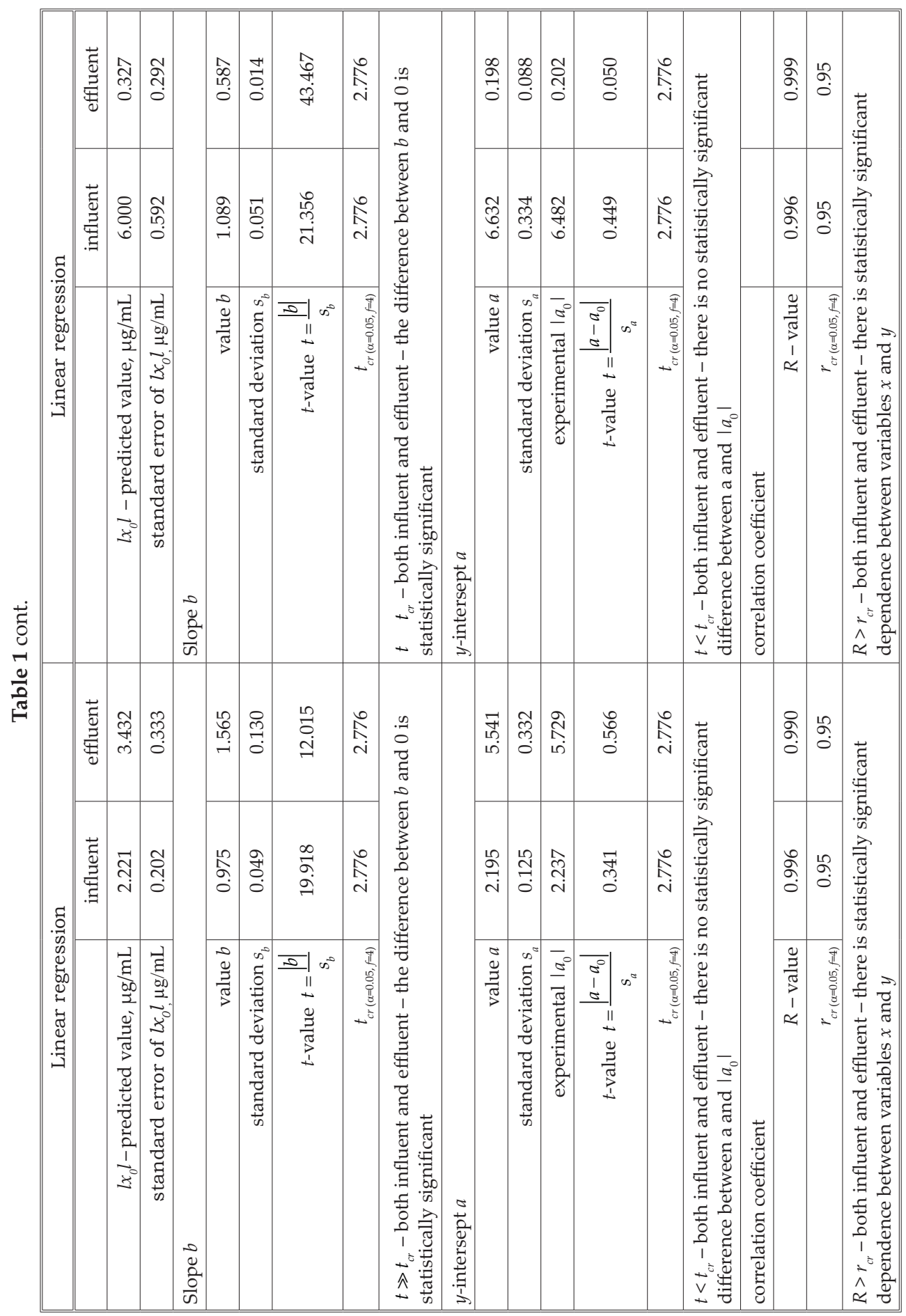




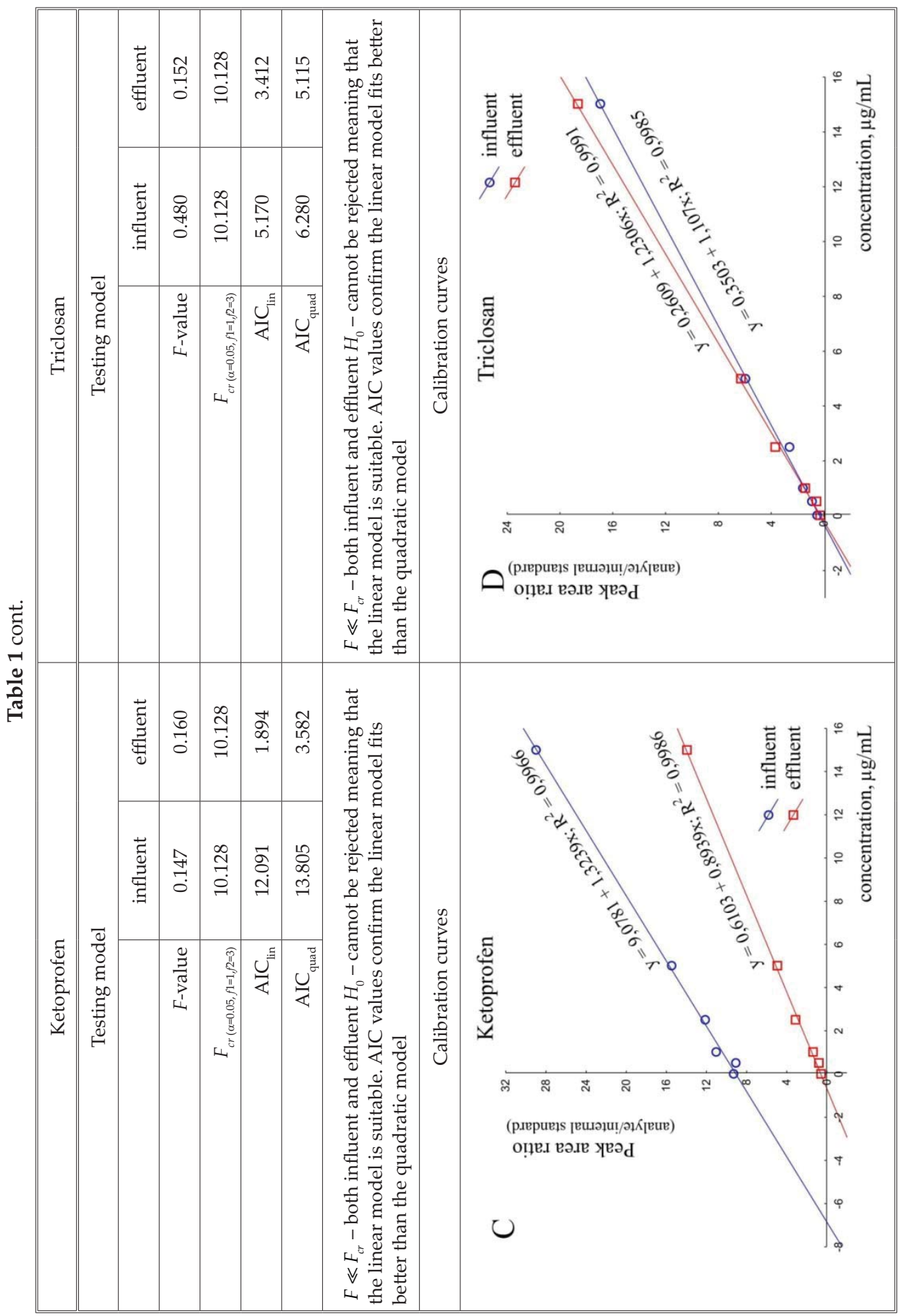




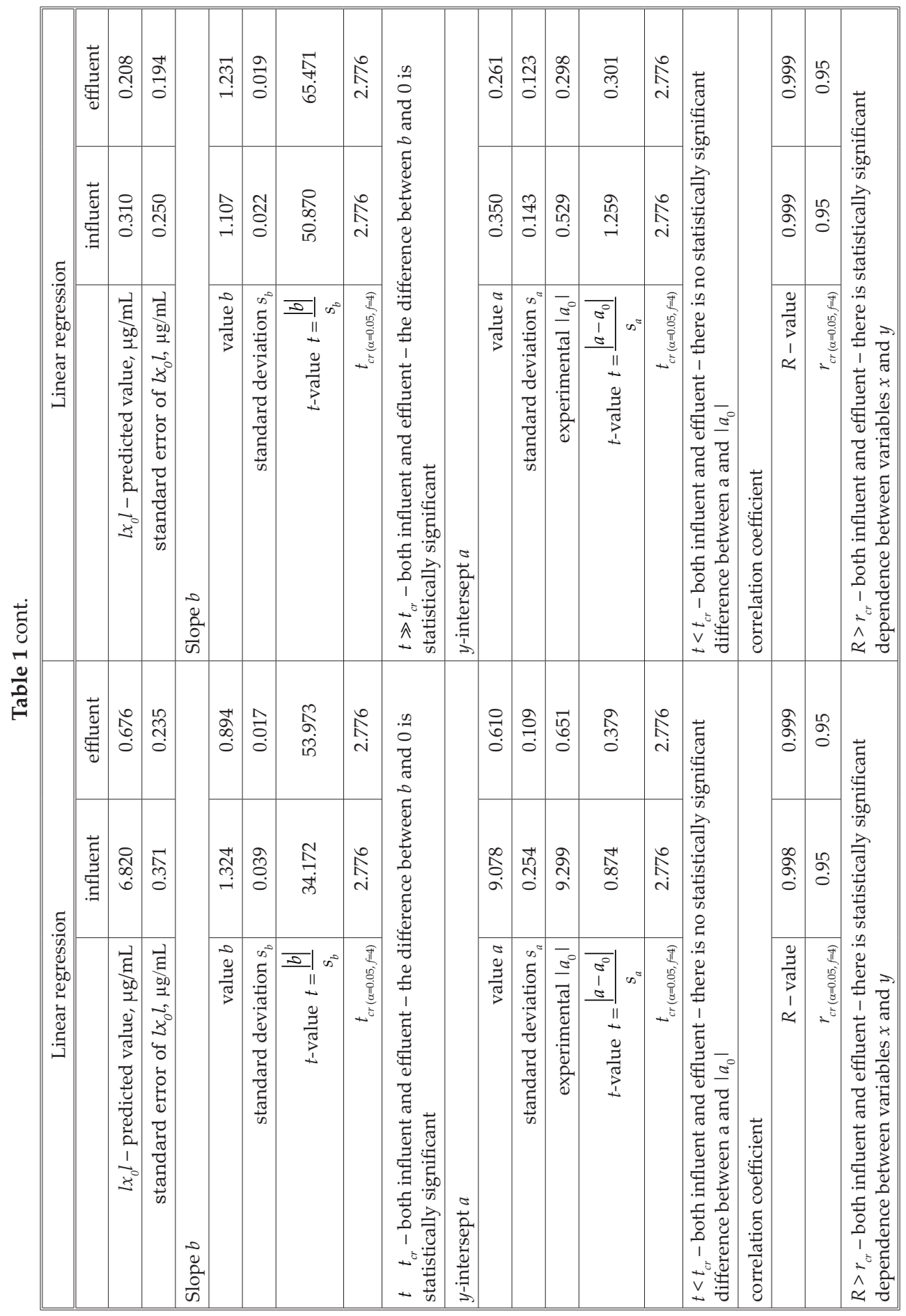




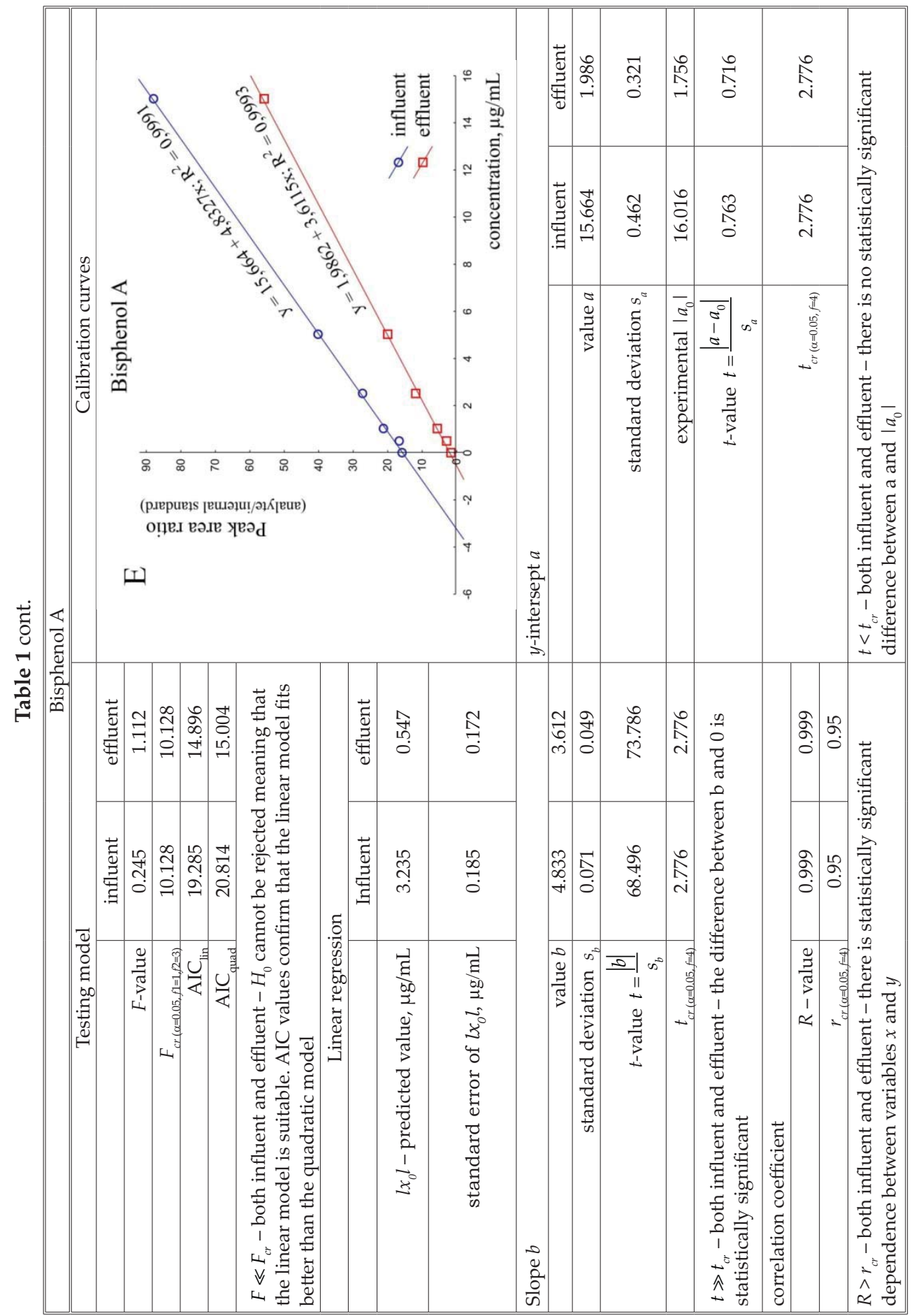




\subsection{GC/MS Analysis}

The chromatographic separation and analysis were performed with the HP 5890 series II gas chromatograph equipped with a split/splitless injector, HP - 5 MS capillary column $(30 \mathrm{~m} \times 0.25 \mathrm{~mm}$ i.d., $0.25 \mu \mathrm{m}$ film thickness, $5 \%$ phenyl $95 \%$ dimethylpolysiloxane stationary phase) and HP 5971 quadrupole mass selective detector (Agilent Technologies, USA).

The injection port temperature was set to $250^{\circ} \mathrm{C}$ and transfer line temperature was $260^{\circ} \mathrm{C}$. The GC oven temperature started at $70^{\circ} \mathrm{C}$ and was held at $70^{\circ} \mathrm{C}$ for $2 \mathrm{~min}$. Then, the temperature was increased to $280^{\circ} \mathrm{C}$ at a heating rate $15^{\circ} \mathrm{C} / \mathrm{min}$ and held at $280^{\circ} \mathrm{C}$ for $7 \mathrm{~min}$ ( $23 \mathrm{~min}$. total run time). The samples in $1 \mu \mathrm{L}$ aliquots were manually injected in splitless mode and then carried to the column by helium gas in constant flow rate of $1 \mathrm{~mL} / \mathrm{min}$. The electron impact ionization potential was $70 \mathrm{eV}$. Identification and quantification of analytes were performed in selected ion monitoring (SIM) mode on the basis of time retention and characteristic fragment ions $(\mathrm{m} / \mathrm{z}, \mathrm{Tab} .2)$ of target compounds.

Table 2. Retention time and $\mathrm{m} / \mathrm{z}$ ratio of characteristic ions of target compounds

\begin{tabular}{||l|c|c||}
\hline \multicolumn{1}{|c|}{ Pharmaceuticals } & Retention time [min] & $\begin{array}{c}m / z \text { for characteristic ions } \\
\text { (for quantification) }\end{array}$ \\
\hline Naproxen & 14.21 & 243,185 \\
\hline Triclosan & 14.53 & $347,200,362$ \\
\hline Ketoprofen & 14.99 & 282,105 \\
\hline Bisphenol A & 15.01 & 357,372 \\
\hline Diclofenac- Na & 15.56 & 214,242 \\
\hline 1-hydroxypyrene & 16.30 & 290 \\
\hline
\end{tabular}

\section{Results}

A statistical analysis confirmed linearity of data in whole tested concentration range giving $R^{2}$ values from 0.9913 to 0.9993 . For diclofenac linearity is limited to the range of $0.5-5.0 \mu \mathrm{g} / \mathrm{mL}$ with $R^{2} 0.9766$ for effluent and 0.9925 for influent. For each pharmaceutical compound, the statistically significance of slope $b$ confirmed the obvious relationship between the concentration and chromatographic signal, both for influent and effluent. Theoretical intercept a in every case is statistically insignificant meaning that our quantitative method works properly.

Results of the determination of pharmaceuticals in wastewater samples with validation parameters are shown in table 3 . Analyte recoveries are considered to be satisfactory, as they ranged from $61 \%$ for triclosan to $78 \%$ for diclofenac. In treated 
wastewater LOD were varied from $0.002 \mu \mathrm{g} / \mathrm{L}$ to $0.016 \mu \mathrm{g} / \mathrm{L}$ whereas in raw wastewater LOD were between $0.006 \mu \mathrm{g} / \mathrm{L}$ to $0.121 \mu \mathrm{g} / \mathrm{L}$.

The data show that all of the tested pharmaceutical substances enter the wastewater treatment plant at trace concentrations ranging from $0.166 \mu \mathrm{g} / \mathrm{L}$ to $4.0 \mu \mathrm{g} / \mathrm{L}$. After all the stages of treatment, reduction in the concentrations of naproxen, ketoprofen and bisphenol A appear to be significant whereas diclofenac was detected in effluent in a similar amount as influent. The results are comparable to those of previous studies conducted at A. Mickiewicz University in Poznań [13]. Similarly, naproxen and ketoprofen were determined in raw wastewater at the highest concentration level (7-10 $\mu \mathrm{g} / \mathrm{L})$, but for these compounds conventional treatment processes were observed to be efficient (significantly lower concentration in effluent comparing to influent), while diclofenac was found to be the most resistant towards the treatment (concentration in influent is comparable to effluent). Low susceptibility of diclofenac to the removal mechanisms was also revealed by other authors $[12,20$, 25]. Anti-bacterial triclosan was detected both in influent and effluent samples at concentration $0.166 \mu \mathrm{g} / \mathrm{L}$ and $0.093 \mu \mathrm{g} / \mathrm{L}$, respectively and these results are comparable to those reported by Weigel and Thomas [27, 29].

Table 3. Concentration of investigated pharmaceuticals in wastewater

\begin{tabular}{|l|c|c|c|c|c|c|c||}
\hline \multirow{2}{*}{ Compound } & \multirow{2}{*}{$\begin{array}{c}\text { Recovery } \\
{[\%]}\end{array}$} & \multicolumn{3}{|c|}{ Influent $[\mu \mathrm{g} / \mathrm{L}]$} & \multicolumn{3}{c||}{ Effluent $[\mu \mathrm{g} / \mathrm{L}]$} \\
\cline { 3 - 8 } & & LOD & LOQ & concentration* & LOD & LOQ & concentration* \\
\hline \hline Naproxen & 64 & 0.121 & 0.362 & $3.513 \pm 0.370$ & 0.016 & 0.048 & $0.140 \pm 0.091$ \\
\hline Triclosan & 61 & 0.012 & 0.036 & $0.166 \pm 0.163$ & 0.010 & 0.031 & $0.093 \pm 0.063$ \\
\hline Ketoprofen & 66 & 0.017 & 0.050 & $4.000 \pm 0.225$ & 0.005 & 0.016 & $0.218 \pm 0.071$ \\
\hline Bisphenol A & 67 & 0.006 & 0.018 & $1.771 \pm 0.111$ & 0.002 & 0.005 & $0.190 \pm 0.051$ \\
\hline Diclofenac $-\mathrm{Na}$ & 78 & 0.020 & 0.001 & $1.132 \pm 0.103$ & 0.010 & 0.020 & $0.875 \pm 0.085$ \\
\hline \hline
\end{tabular}

${ }^{*} \pm$ value - standard error of predicted $x$-value (converted to $\mu \mathrm{g} / \mathrm{L}$ ) for $y=0$ in the regression.

According to the literature data, conventional treatment plants remove pharmaceuticals compounds mainly during biological treatment with activated sludge $[18,22,28]$. Here, biodegradation or sorption to sludge is the probable mechanism of elimination [31]. Removal of acidic compounds is achieved mostly by the biodegradation process. More lipophilic substances (triclosan) may be additionally eliminated with fat separation, during primary treatment and adsorbed onto solid surfaces (sludge) [31]. Low removal rates of diclofenac or even higher contents in effluent might be attributed to the hydrolysis of diclofenac glucuronides under treatment procedures and/or its desorption from particles [20]. 
The performance of the wastewater treatment plant towards the tested pharmaceuticals is not fully representative, because wastewater samples were collected only at one time (early morning). Nevertheless, the results allow us to estimate approximate the pharmaceutical contaminants load in wastewater generated by an urban community and an average amount of pharmaceutical discharge daily into surface water. It should be noted that the main aim of this work was to present an effective and sensitive method enabling us to determine pharmaceutical trace compounds in a complex matrix. Obviously, the preliminary results should be supported with extended studies.

\section{Conclusion}

The paper presents a versatile method useful for the determination of selected emerging contaminants in aquatic environment. Such a tool is highly required since the presence of residual pharmaceutics in the environment is becoming more and more an important ecological issue. A version of the analytical method described in this study, based on SPE and GC/MS is suitable for the analysis of acidic pharmaceuticals residues in wastewaters samples. An analysis of trace compounds in wastewater is difficult due to complexity of the matrix and high organic content. A method has been successfully applied to the analysis of several popular pharmaceutical compounds in wastewater samples even at the low $\mu \mathrm{g} / \mathrm{L}$ level and provided satisfactory recoveries and precision.

\section{References}

[1] Barnes K.K., Kolpin D.W., Furlong E.T., Zaugg S.D., Meyer M.T., Barber L.B.: A national reconnaissance of pharmaceuticals and other organic wastewater contaminants in the United States. I: Groundwater. Science of the Total Environment, vol. 402, no. 2-3, 2008, pp. 192-200.

[2] Boyd G.R., Reemtsma H., Grimm D.A., Mitra S.: Pharmaceuticals and personal care products (PPCPS) in surface and treated waters of Louisiana, USA and Ontario, Canada. The Science of the Total Environment, vol. 311, no. 1-3, 2003, pp. 135-149.

[3] Carballa M., Omil F., Lema J.M., Llompart M., García-Jares C., Rodríguez I., Gómez M., Ternes T.: Behavior of pharmaceuticals, cosmetics and hormones in a sewage treatment plant. Water Research, vol. 38, no. 12, 2004, pp. 2918-2926.

[4] Danzer K., Currie L.A.: Guidelines for calibration in analytical chemistry. Part 1: Fundamentals and single component calibration. Pure \& Applied Chemistry, vol. 70, no. 4, 1998, pp. 993-1014. 
[5] Dębska J., Kot-Wasik A., Namieśnik J.: Determination of nonsteroidal antiinflammatory drugs in water samples using liquid chromatography coupled with diode-array detector and mass spectrometry. Journal of Separation Science, vol. 28, no. 17, 2005, pp. 2419-2426.

[6] Dębska J., Kot-Wasik A., Namieśnik J.: Fate and Analysis of Pharmaceutical Residues in the Aquatic Environment. Critical Reviews in Analytical Chemistry, vol. 34, no. 1, 2004, pp. 51-67.

[7] Felis E., Miksch K., Surmacz-Górska J., Ternes T.: Presence of pharmaceutics in wastewater from waste water treatment plant "Zabrze-Śródmieście" in Poland. Archives of Environmental Protection, vol. 31, no. 3, 2005, pp. 49-58.

[8] Focazio M.J., Kolpin D.W., Barnes K.K., Furlong E.T., Meyer M.T., Zaugg S.D., Barber L.B., Thurman M.E.: A national reconnaissance for pharmaceuticals and other organic wastewater contaminants in the United States. II: Untreated drinking water sources. Science of The Total Environment, vol. 402, no. 2-3, 2008, pp. 201-216.

[9] Garrison A.W., Pope J.D., Allen F.R.: Analysis of organic compounds in domestic wastewater. [in:] Keith C.H. (ed.), Identification and analysis of organic pollutants, Ann Arbor Science Publisher, Ann Arbor, 1976, pp. 517-556.

[10] Halling-Sorensen B., Nielsen N.S., Lanzky S.F., Ingerslev F.: Occurrence, fate, and effects of pharmaceutical substances in the environment - a review. Chemosphere, vol. 36, no. 2, 1998, pp. 357-393.

[11] Heberer T.: Occurrence, fate, and removal of pharmaceutical residues in the aquatic environment: a review of recent research data. Toxicology Letters, vol. 131, no. 1-2, 2002, pp. 5-17.

[12] Heberer T., Reddersen K., Mechlinski A.: From municipal sewage to drinking water: fate and removal of pharmaceutical residues in the aquatic environment in urban areas. Water Science and Technology, vol. 46, no. 3, 2002, pp. 81-88.

[13] Kasprzyk-Hordern B., Dąbrowska A., Vieno N., Kronberg L., Nawrocki J.: Occurrence of Acidic Pharmaceuticals in the Warta River in Poland. Chemical Analysis, vol. 53, no. 2, 2008, pp. 289-304.

[14] Kasprzyk-Hordern B., Dinsdale R.M., Guwy A.J.: Multi-residue method for the determination of basic/neutral pharmaceuticals and illicit drugs in surface water by solid-phase extraction and ultra performance liquid chromatography-positive electrospray ionisation tandem mass spectrometry. Journal of Chromatography A, vol. 1161, no. 1-2, 2007, pp. 132-145.

[15] Konieczko P., Namieśnik J.: Ocena i kontrola jakości wyników pomiarów analitycznych, Wydawnictwa Naukowo-Techniczne, Warszawa 2007.

[16] PMR Publications: Rynek farmaceutyczny i ochrony zdrowia w Polsce 2009 - prognozy rozwoju na lata 2009-2011, [on line:] www.pmrpublications.com.

[17] PMR Publications: Rynek farmaceutyczny w Polsce: w latach 2011-2013 tylko umiarkowany wzrost, [on line:] www.pmrpublications.com. 
[18] Radjenovic J., Petrovic M., Barcelo D., Petrovic M.: Advanced mass spectrometric methods applied to the study of fate and removal of pharmaceuticals in wastewater treatment. TrAC Trends in Analytical Chemistry, vol. 26, no. 11, 2007, pp. 1132-1144.

[19] Santos J.L., Aparicio I., Alonso E., Callejón M.: Simultaneous determination of pharmaceutically active compounds in wastewater samples by solid phase extraction and high-performance liquid chromatography with diode array and fluorescence detectors. Analytica Chimica Acta, vol. 550, no. 1-2, 2005, pp. 116-122.

[20] Sebok Á., Vasanits-Zsigrai A., Palkó G., Záray G., Molnár-Perl I.: Identification and quantification of ibuprofen, naproxen, ketoprofen and diclofenac present in waste-waters, as their trimethylsilyl derivatives, by gas chromatography mass spectrometry. Talanta, vol. 76, no. 3, 2008, pp. 642-650.

[21] Sosnowska K., Styszko K., Gołaś J.: Wstẹpne oznaczenie wybranych farmaceutyków w ściekach komunalnych z oczyszczalni Kraków Płaszów. Proceedings of ECOpole, vol. 5, no. 2, 2011, pp. 601-608.

[22] Staples C.A., Dorn P.B., Klecka G.M., O'Block S.T., Harris L.R.: A review of the environmental fate, effects and exposures of bisphenol A. Chemosphere, vol. 36, no. 10, pp. 2149-2173.

[23] Styszko-Grochowiak K., Sosnowska K., Gołaś J.: Problem występowania farmaceutyków w środowisku wodnym. Gaz, Woda i Technika Sanitarna, no. 9, 2009, pp. 52-53.

[24] Styszko K., Sosnowska K., Górecki J., Macherzyński M., Gołaś J.: Optymalizacja warunków derywatyzacji wybranych związów z grupy nowopojawiajacych się zanieczyszczeń. VIII Polska Konferencja Chemii Analitycznej „Analityka dla społeczeństwa XXI wieku”, Uniwersytet Jagielloński, Komitet Chemii Analitycznej, Polskie Towarzystwo Chemiczne, Kraków 2010, p. 91.

[25] Tauxe-Wuersch A., Alencastro L.F.D., Grandjean D., Tarradellas J.: Occurrence of several acidic drugs in sewage treatment plants in Switzerland and risk assessment. Water Research, vol. 39, no. 9, 2005, pp. 1761-1772.

[26] Ternes T.A.: Occurrence of drugs in German sewage treatment plants and rivers. Water Research, vol. 32, no. 11, 1998, pp. 3245-3260.

[27] Thomas P.M., Foster G.D.: Determination of Nonsteroidal Anti-inflammatory Drugs, Caffeine, and Triclosan in Wastewater by Gas Chromatography-Mass Spectrometry. Journal of Environmental Science and Health, Part A, vol. 39, no. 8, 2004, pp. 1969-1978.

[28] Thompson A., Griffin P., Stuetz R. and Cartmell E.: The Fate and Removal of Triclosan during Wastewater Treatment. Water Environment Research, vol. 77, no. 1, 2005, pp. 63-67.

[29] Weigel S., Berger U., Jensen E., Kallenborn R., Thoresen H. and Hühnerfuss $\mathrm{H}$.: Determination of selected pharmaceuticals and caffeine in sewage and seawater from Tromso/Norway with emphasis on ibuprofen and its metabolites. Chemosphere, vol. 56, no. 6, 2004, pp. 583-592. 
[30] [30] Weigel S., Kallenborn R., Hühnerfuss H.: Simultaneous solid-phase extraction of acidic, neutral and basic pharmaceuticals from aqueous samples at ambient (neutral) $\mathrm{pH}$ and their determination by gas chromatography-mass spectrometry. Journal of Chromatography A, vol. 1023, no. 2, 2004, pp. 183-195.

[31] [31] Zorita S., Mårtensson L., Mathiasson L.: Occurrence and removal of pharmaceuticals in a municipal sewage treatment system in the south of Sweden. Science of The Total Environment, vol. 407, no. 8, 2009, pp. 2760-2770. 